\title{
Human Erythrocyte Protein 4.1 Is a Phosphatidylserine Binding Protein
}

\author{
Anne C. Rybicki, Russell Heath, Bertram Lubin, and Robert S. Schwartz \\ Children's Hospital Medical Center, Bruce Lyon Memorial Research Laboratory, Oakland, California 94609
}

\begin{abstract}
The aminophospholipids phosphatidylethanolamine (PE) and phosphatidylserine (PS) are the major phospholipids contained in the cytoplasmic leaflet of the human erythrocyte (RBC) plasma membrane and are largely confined to that leaflet over the entire RBC lifespan. In particular, PS, which comprises $\sim 13 \%$ of total RBC membrane phospholipids, is normally restricted entirely to the cytoplasmic leaflet. However, molecular mechanisms that regulate this asymmetric distribution of phospholipids are largely unknown. We examined elliptocytic RBCs that completely lacked protein 4.1 (HE[4.1 $\left.{ }^{\circ}\right)$, but contained normal amounts of all other peripheral membrane proteins, and found $\sim 10 \%$ of total membrane PS was accessible in the exoplasmic leaflet of these membranes. Inside out vesicles (IOVs) derived from HE[4.1 ${ }^{\circ}$ RBCs bound fewer PS liposomes than did IOVs derived from normal RBCs. Normal IOVs that were depleted of proteins 2.1 (ankyrin), 4.1, and 4.2 bound fewer PS liposomes similar to HE[4.1 ${ }^{\circ}$ IOVs, and repletion with protein 4.1 restored PS liposome binding to control levels. Addition of purified protein 4.1 to PS liposomes resulted in saturable binding with the extent of binding being proportional to the liposome PS content. Our data suggests that human RBC protein 4.1 is a PS binding protein and may be involved in the molecular mechanisms that stabilize PS in the cytoplasmic leaflet of the human RBC plasma membrane.
\end{abstract}

\section{Introduction}

It is now well established that the phospholipids that comprise the human erythrocyte $(\mathrm{RBC})^{1}$ plasma membrane are arranged asymmetrically between the bilayer leaflets (1). This asymmetric organization results in the exoplasmic leaflet being enriched in the choline-containing phospholipids, phosphatidylcholine (PC) and sphingomyelin (SM), and the cytoplasmic leaflet being enriched in the aminophospholipids, phosphatidylethanolamine (PE), and phosphatidylserine (PS). Notably,

A portion of this work was previously presented in preliminary form (1984. Blood. 64[Suppl. 1]:30).

Address reprint requests to Dr. A. C. Rybicki, Albert Einstein College of Medicine-Montefiore Hospital Medical Center, Hematology Department, Central 221, 111 East 210th St., Bronx, NY 10467. 1987.

Received for publication $10 \mathrm{May} 1985$ and in revised form $20 \mathrm{May}$

1. Abbreviations used in this paper: IOV, inside out vesicle; PC, phosphatidylcholine; PE, phosphatidylethanolamine; PLA 2 , phospholipase $\mathrm{A}_{2}$; PS, phosphatidyldylserine; SM, sphingomyelin; SMC, sphingomyelinase $\mathrm{C}$; RBC, erythrocyte.

J. Clin. Invest.

(c) The American Society for Clinical Investigation, Inc.

$0021-9738 / 88 / 01 / 0255 / 06 \$ 2.00$

Volume 81, January 1988, 255-260
PS is found only in the cytoplasmic leaflet. Recently, it has been shown that this arrangement is not static and that dynamic transbilayer movement (i.e., flip-flop) of some phospholipids does occur (2-4). That the asymmetric organization of phospholipids is maintained throughout the 120 -d average lifespan of RBCs (5) implies that some mechanism must exist to stabilize specific phospholipids within bilayer leaflets. It has been suggested that spectrin is involved in this process since spectrin interacts with aminophospholipids in lipid monolayers (6), phospholipid vesicles (7), and in intact RBCs (8). Also, partial loss of membrane phospholipid asymmetry occurs upon depletion of RBC membranes of spectrin during preparation of inside out vesicles (IOVs) in vitro (9), and in spectrin-free microvesicles spontaneously released from aged $\operatorname{RBC}(10,11)$.

The present work examines the contribution of protein 4.1 towards the maintenance of RBC membrane phospholipid asymmetry. Protein 4.1 is known to bind to the distal end of the spectrin tetramer (12), associate with the cytoplasmic domain of integral membrane glycophorins $(13,14)$, and interact with protease digested IOVs (15). We examined RBCs from a patient with homozygous hereditary elliptocytosis whose membranes completely lacked protein $4.1\left(\mathrm{HE}\left[4.1^{\circ}\right]\right)^{2}$ but contained normal amounts of all other membrane cytoskeletal proteins. In addition to an abnormal cell morphology, the exoplasmic bilayer leaflet of these $\mathrm{HE}\left[4.1^{\circ}\right] \mathrm{RBCs}$ contained PS. We also evaluated the interaction of protein 4.1 with phospholipid model membranes (liposomes) and found that protein 4.1 interacts specifically and saturably with liposomes containing PS. Taken together, these studies suggest that interactions between protein 4.1 and PS occur in RBC membranes and may contribute to the maintenance of membrane PS asymmetry.

\section{Methods}

Materials. PS from bovine brain and PC from egg yolk were purchased from Avanti Polar Lipids, Inc., Birmingham, AL. Lipids migrated as single spots on TLC and were stored under nitrogen in sealed vials at $-70^{\circ} \mathrm{C}$ until used. $\left[{ }^{3} \mathrm{H}\right]$ triolein and ${ }^{125} \mathrm{I}$-Bolton Hunter reagent were obtained from New England Nuclear, Boston, MA. Dialysis tubing (Spectrapor-2) was from Spectrum Medical, Los Angeles, CA. DTT was from Calbiochem-Behring Corp., La Jolla, CA. Sphingomyelinase C (SMC) from Staphylococcus aureus was the generous gift of Drs. B. Roelofsen and L. L. M. van Deenen, Utrecht, Netherlands. Phospholipase $\mathrm{A}_{2}\left(\mathrm{PLA}_{2}\right)$ from bee venom and Ficoll 400 were from Sigma Chemical Co., St. Louis, MO. All gel electrophoresis reagents were electrophoretic grade from Bio-Rad Laboratories, Richmond, CA. All other chemicals were reagent grade from standard sources.

Blood collection, RBC ghost, and membrane vesicle preparation. After obtaining informed consent, fresh blood samples from a patient with hereditary elliptocytosis whose RBCs were completely deficient in protein $4.1\left(\mathrm{HE}\left[4.1^{\circ}\right]\right)$ and from healthy normal controls were col-

2. Nomenclature suggested by J. Palek and S. E. Lux to describe RBC membrane cytoskeletal defects (1983. Semin. Hematol. 20:189-224). 
lected in acid citrate dextrose. RBC ghosts were prepared by the method of Dodge et al. (16), except that $0.4 \mathrm{mM}$ diisopropylfluorophosphate was added at the lysis step. Spectrin-actin-depleted IOVs from normal and $\mathrm{HE}\left[4.1^{\circ}\right]$ ghosts were prepared by the method of Steck and Kant (17). IOV membrane sidedness was determined by glyceraldehyde-3-phosphate dehydrogenase and acetylcholinesterase assays (18). Some of the normal IOVs were further depleted of ankyrin, protein 4.1 , and protein 4.2 by the potassium iodide method of Bennett and Stenbuck (19). Protein 4.1 was reassociated with protein 4.1depleted IOVs by the method of Shiffer and Goodman (20).

Treatment of $R B C s$ with $P L A_{2}$ and SMC. Normal and HE[4.1 $\left.{ }^{\circ}\right]$ RBCs were treated with $\mathrm{PLA}_{2}$ for $1 \mathrm{~h}$ at $37^{\circ} \mathrm{C}$ followed by SMC for $1 \mathrm{~h}$ at $37^{\circ} \mathrm{C}$, according to the procedure of Lubin et al. (21). Phospholipid degradation was terminated by washing RBCs three times with PBS containing $5 \mathrm{mM}$ EDTA. The extent of cell hemolysis was determined by comparing the hemoglobin content in each sample supernate with hemolyzed controls. Lipid extraction was by the method of Rose and Oklander (22). Individual phospholipid classes were separated by the two-dimensional TLC technique of Roelofsen and Zwaal (23). Separated phospholipids were stained, extracted from the TLC plates, and quantitated by phosphorus determination, as described by Bartlett (24).

Preparation of liposomes. Unilamellar liposomes composed of varying molar ratios of PS and PC were prepared by the reverse phase evaporation technique of Szoka and Papahadjopoulos (25), with some modifications (26). In some experiments, the nontransferable phospholipid $\left[{ }^{3} \mathrm{H}\right]$ triolein was added in trace amounts $(0.007 \%$ of total lipid) to allow quantitation of liposome binding. After the vesicles were formed, they were uniformly sized to $100 \mathrm{~nm}$ by extrusion through polycarbonate membranes (Bio-Rad Laboratories) $(27,28)$. Liposomes were stored under argon at $4^{\circ} \mathrm{C}$ and were used within 1 wk of their preparation. The concentration of phospholipid in the liposome preparations was determined by phosphorus assay (24).

Purification and radiolabeling of protein 4.1. Protein 4.1 was purified from RBCs by the method of Tyler et al. (29), with modifications by Cohen and Foley (30). For some experiments, protein 4.1 was denatured by heating at $65^{\circ} \mathrm{C}$ for $20 \mathrm{~min}$. In our hands, heat-denatured protein 4.1 did not sediment at the concentrations used in these studies. Protein determinations were performed by the method of Bradford (31). SDS-PAGE was performed as described by Laemmli (32), and the protein bands were quantitated by densitometry of Coomassie Brilliant Blue stained gels. For some experiments protein 4.1 was radiolabeled with ${ }^{125}$ I-Bolton Hunter reagent (33). Protein 4.1 was used when prepared, or in some cases, stored in siliclad-treated polycarbonate tubes at $-70^{\circ} \mathrm{C}$ in PBS containing $20 \mathrm{mM}$ potassium chloride, $1 \mathrm{mM}$ disodium EDTA, $0.2 \mathrm{mM}$ DTT, and $0.4 \mathrm{mM}$ diisopropylfluorophosphate.

IOV binding to liposomes. IOVs (12 $\mu \mathrm{g}$ phosphorus) were incubated at $37^{\circ} \mathrm{C}$ for $1 \mathrm{~h}$ with $40 \mathrm{nmol}$ radiolabeled liposomes (PS/PC, 3:1 molar ratio) in a total volume of $0.2 \mathrm{ml}$ buffer $\mathrm{A}(20 \mathrm{mM}$ sodium Hepes, $\mathrm{pH} 7.4$, containing $140 \mathrm{mM} \mathrm{NaCl}$ ). After the incubation, the liposome-IOV complex was sedimented at $39,000 \mathrm{~g}$ for $30 \mathrm{~min}$ at $4^{\circ} \mathrm{C}$ and washed twice in buffer $\mathrm{A}$. The amount of membrane-bound liposomes was determined by the radioactivity contained in the washed IOV pellets.

Protein 4.1 binding to liposomes. ${ }^{125}$ I-Protein 4.1 was incubated with liposomes ( $50 \mu \mathrm{mol}$ lipid) in siliclad-coated polycarbonate tubes in a total volume of $0.25 \mathrm{ml}$ buffer $\mathrm{A}$ at $37^{\circ} \mathrm{C}$ for $30 \mathrm{~min}$. Liposomebound protein was separated from unbound protein by flotation through a Ficoll 400 discontinuous density gradient as follows: a stock solution of $30 \%$ Ficoll 400 was added to the ${ }^{125} \mathrm{I}$-protein 4.1-liposome incubation mixture to a final concentration of $3 \mathrm{ml} 10 \%$ Ficoll. Siliclad-treated $13 \times 51 \mathrm{~mm}$ polyallomer ultracentrifuge tubes were layered (from bottom to top of tube) with $1 \mathrm{ml}$ of $30 \%$ Ficoll $400,3 \mathrm{ml}$ of the $10 \%$ Ficoll-liposome-protein 4.1 incubation mixture, and 0.5 $\mathrm{ml}$ of buffer $\mathrm{A}$. The gradient was centrifuged for $1 \mathrm{~h}$ at $25^{\circ} \mathrm{C}$ (model SW 50.1 swinging bucket rotor at $35,000 \mathrm{rpm}$ in a model L8-80 ultracentrifuge; Beckman Instruments, Inc., Fullerton, CA). Protein 4.1 binding to liposomes was determined from the ${ }^{125} \mathrm{I}$-protein 4.1 and phosphorus (liposome) content of the top $0.8 \mathrm{ml}$ (liposome containing portion) of the gradient. Samples were run in duplicate and the duplicates varied by no more than $5 \%$.

\section{Results}

Bilayer distribution of membrane phospholipids in normal and $H E\left[4.1^{\circ}\right] R B C . \mathrm{RBC}$ membranes from a patient with homozygous hereditary elliptocytis (HE[4.1 $\left.{ }^{\circ}\right]$ ) differed from normal RBCs in that they were completely deficient in protein 4.1 , as shown by both SDS-PAGE and immunologic characterization (Fig. 1). When $\mathrm{HE}\left[4.1^{\circ}\right.$ ] RBCs were subjected to analysis of membrane phospholipid sidedness, we found that $\sim 10 \%$ of the total membrane content of PS was available for degradation using the combination of $\mathrm{PLA}_{2}$ plus SMC, whereas there was no degradation of PS in normal RBCs identically treated (Table I). Treatment of HE[4.1 $\left.{ }^{\circ}\right]$ RBCs with PLA $_{2}$ plus SMC at the levels used in these experiments did not produce significant cell hemolysis (6\%). In the HE[4.1 $\left.{ }^{\circ}\right] \mathrm{RBCs}$ there was also a 9\% decrease in the exoplasmic leaflet content of PC, presumably to offset the movement of PS into this leaflet and maintain an equimolar distribution of phospholipids in each bilayer leaflet.

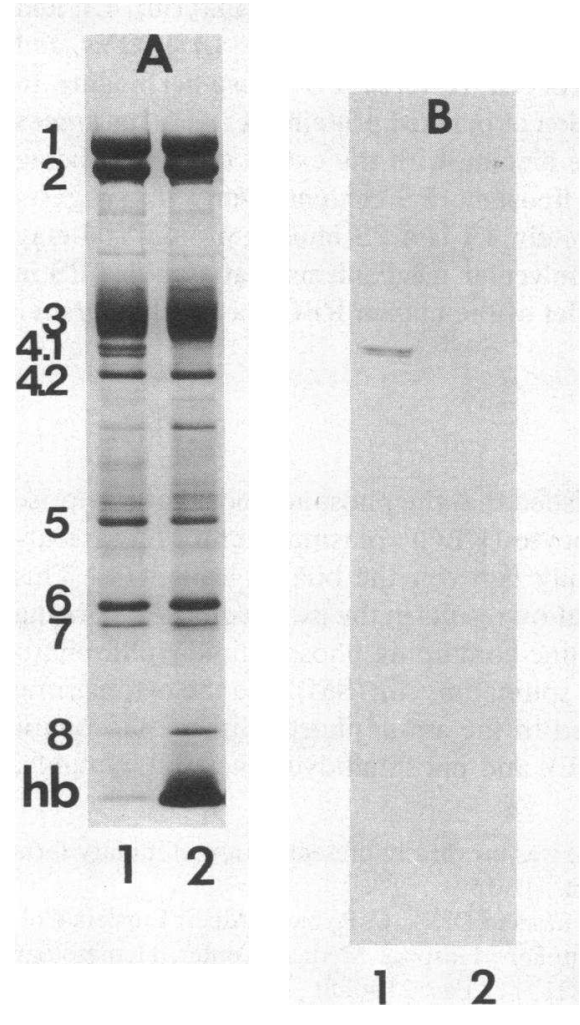

Figure 1. (A) Protein composition of normal and HE[4.1 $\left.{ }^{\circ}\right]$ RBC ghost membranes. Proteins from normal (lane 1 ) and $\mathrm{HE}\left[4.1^{\circ}\right]$ (lane 2) ghost membranes $(20 \mu \mathrm{g})$ were separated by SDS-PAGE $(6-15 \%$ linear gradient). The nomenclature of the polypeptide bands is according to Steck (34). (B) Immunoblot of normal (lane 1 ) and $\mathrm{HE}\left[4.1^{\circ}\right]$ (lane 2$)$ ghost membranes. Proteins $(20 \mu \mathrm{g})$ were transferred to nitrocellulose paper that was incubated with monospecific rabbit anti-human $\mathrm{RBC}$ protein $4.1 \mathrm{IgG}$ and the antigen-antibody complex visualized with goat anti-rabbit IgG horseradish peroxidase conjugate followed by color development with 4-chloro-1-naphthol (35). 
Table I. Membrane Phospholipid Organization in Normal, Protein 4.1-deficient (HE[4.1 $\left.{ }^{\circ}\right]$ ), and Glycophorin C-deficient $\left(G e^{-}\right)$Human $R B C s$

\begin{tabular}{llllll}
\hline & \multicolumn{3}{l}{ Phospholipid degraded } & & \\
\cline { 2 - 5 } RBC & PC & PE & PS & SM & Hemolysis \\
\hline & $\%$ & $\%$ & $\%$ & $\%$ & $\%$ \\
Normal & $78 \pm 6$ & $23 \pm 4$ & 0 & $63 \pm 6$ & $3 \pm 2$ \\
HE $\left[4.1^{\circ}\right]$ & $70 \pm 8^{*}$ & $21 \pm 3$ & $10 \pm 3^{*}$ & $63 \pm 7$ & $6 \pm 2$ \\
$\mathrm{Ge}^{-}$ & $74 \pm 5$ & $22 \pm 2$ & 0 & $65 \pm 5$ & $3 \pm 2$ \\
\hline
\end{tabular}

RBCs were treated with bee venom PLA $\mathrm{A}_{2}$ for $1 \mathrm{~h}$ at $37^{\circ} \mathrm{C}$ followed by Staphylococcus aureus SMC for $1 \mathrm{~h}$ at $37^{\circ} \mathrm{C}$. Percentage phospholipid degradation was determined as described in Methods. Results are the mean \pm 1 SD of 10 determinations.

* Statistically different from normal at $P<0.01$.

Since these HE $\left[4.1^{\circ}\right]$ RBC membranes are also $>80 \%$ deficient of glycophorin C (14), it was possible that the loss of PS asymmetry in the $\mathrm{HE}\left[4.1^{\circ}\right]$ membranes was related to the deficiency of this protein and not to the deficiency of protein 4.1. To examine this, we determined membrane phospholipid sidedness in RBCs lacking the Gerbich blood group antigen $\left(\mathrm{Ge}^{-}\right) . \mathrm{Ge}^{-} \mathrm{RBCs}$ differ from normal RBCs in that they completely lack glycophorin $C$, but contain normal amounts of all other cytoskeletal proteins (Fig. 2 and reference 36). We found, as previously reported by Kuypers et al. (39), that the bilayer distribution of membrane phospholipids was normal in $\mathrm{Ge}^{-}$cells (Table I), indicating that the loss of PS asymmetry in the HE[4.1 $\left.{ }^{\circ}\right]$ RBCs was not related to the deficiency of glycophorin C.

Binding of RBC membrane vesicles to PS liposomes. Incubation of spectrin-actin-depleted IOVs derived from normal RBCs with PS-containing liposomes (PS/PC, 3:1 molar ratio) resulted in liposome binding (Table II). Similar incubation of liposomes with IOVs derived from HE[4.1 $\left.{ }^{\circ}\right] \mathrm{RBCs}$ or with IOVs that were stripped of proteins 2.1 (ankyrin), 4.1, and 4.2 resulted in a $20 \%$ decrease in liposome binding. Reassociation of protein 4.1 with the stripped IOVs restored PS liposome binding to control values.

Effect of phospholipid species on protein 4.1-liposome binding. To further characterize the interaction of protein 4.1 with PS, we incubated liposomes containing varying molar ratios of $P S$ and $P C$ with radiolabeled protein 4.1. Liposomebound protein was separated from unbound protein by centrifugation of the liposome-protein 4.1 mixture through a Ficoll 400 discontinuous density gradient. In this method, liposomebound protein floats to the top of the gradient (Ficoll-buffer interface), whereas unbound protein remains in the gradient (Fig. 3). We found that the extent of protein 4.1 binding to liposomes was directly proportional to the liposome PS content (Fig. 4). Binding of protein 4.1 to $100 \%$ PC liposomes was $\sim 15 \%$ of binding to $100 \%$ PS liposomes and may represent nonspecific protein binding. A binding isotherm performed with protein 4.1 and $100 \%$ PS liposomes demonstrated saturable binding; saturating at $\sim 100 \mu \mathrm{g}$ protein $4.1 / \mu \mathrm{mol}$ PS (Fig. 5). Similar studies employing $100 \%$ PC liposomes showed that protein 4.1 binding was never $>5 \%$ of the binding to $100 \%$ PS liposomes (data not shown). To ascertain whether radiolabeling protein 4.1 had denatured or altered the protein, thereby affecting its association with liposomes, we evaluated the specific radioactivity of protein 4.1 before and after incubation with PS liposomes. We found that the specific radioactivity of unbound and liposome-bound ${ }^{125}$ I-protein 4.1 was essentially unchanged (unbound, $4,892 \mathrm{cpm} / \mu \mathrm{g}$ protein and bound, 4,861 $\mathrm{cpm} / \mu \mathrm{g}$ protein). Furthermore, the extent of protein 4.1 liposome binding was identical using high specific radioactivity protein $(150,000 \mathrm{cpm} / \mu \mathrm{g})$ and low specific radioactivity protein $(5,000 \mathrm{cpm} / \mu \mathrm{g})$. These results demonstrate that iodinating the protein with the Bolton Hunter reagent does not affect its ability to bind PS liposomes, nor does it result in a selective population of protein 4.1 molecules that have unique PS binding characteristics.
A

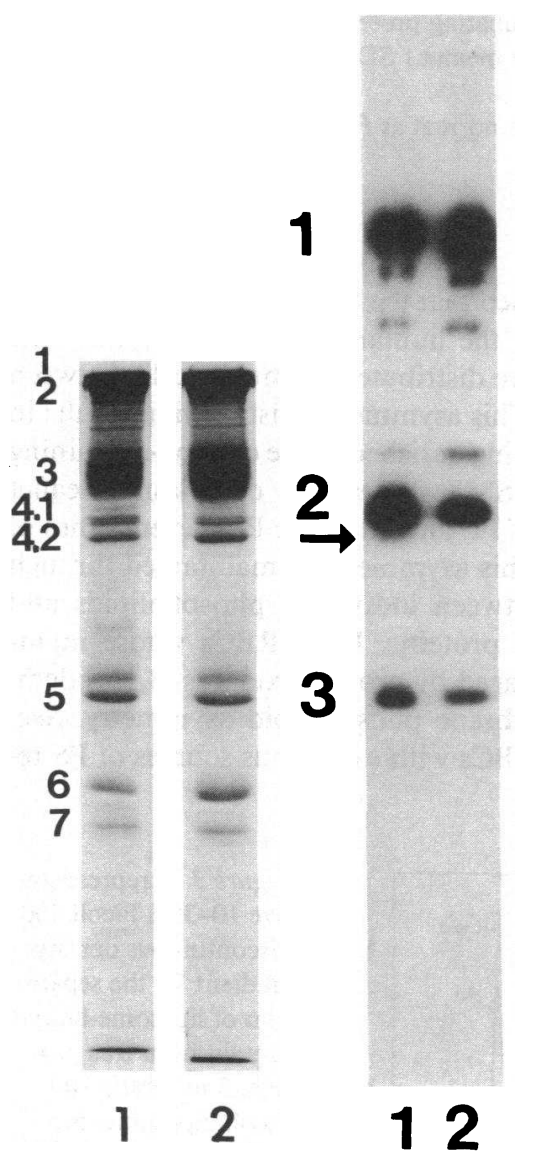

C

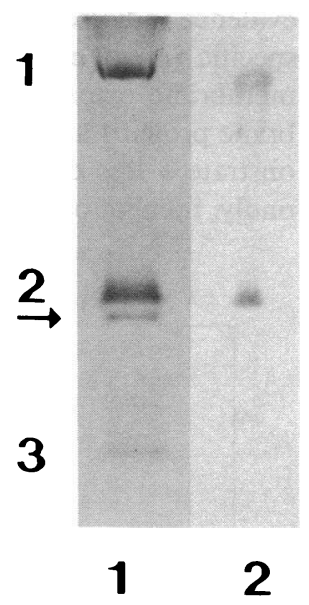

Figure 2. (A) Protein composition of normal and $\mathrm{Ge}^{-} \mathrm{RBC}$ ghost membranes. Proteins from normal (lane 1) and $\mathrm{Ge}^{-}$(lane 2) ghost membranes $(20 \mu \mathrm{g})$ were separated by SDS-PAGE ( $9 \%$ acrylamide). The nomenclature of the polypeptide bands is according to Steck (34). (B) Fluorograph of gel shown in $A$ using the Western immunoblotting technique (35). The blots were incubated with human antiglycohorin antibodies followed by ${ }^{125} \mathrm{I}$-protein $\mathrm{A}$ and exposed to Kodak XAR-5 film for $2 \mathrm{~d}$, as described by Lu et al. (37). The nomenclature of the glycophorins is according to Steck (34). The arrow indicates the position of glycophorin C. $(C)$ Periodic acid-Schiff's base stain (38) of gel shown in $A$. The arrow indicates the position of glycophorin $\mathrm{C}$. 
Table II. Liposome Binding to Normal, Protein 4.1-deficient (HE[4.1 $\left.\left.{ }^{\circ}\right]\right)$, Protein 4.1-depleted, and Protein 4.1-repleted IOVS

\begin{tabular}{|c|c|c|}
\hline IOVs & IOV protein 4.1 content & IOV liposome binding \\
\hline & $\%$ of normal & 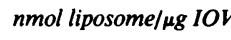 \\
\hline Normal & 100 & $4.7 \pm 0.1$ \\
\hline $\operatorname{HE}\left[4.1^{\circ}\right]$ & 0 & $3.9 \pm 0.4^{*}$ \\
\hline Protein 4.1 depleted & 18 & $3.9 \pm 0.2^{*}$ \\
\hline Protein 4.1 repleted & 110 & $4.6 \pm 0.6$ \\
\hline
\end{tabular}

IOVs were incubated with radiolabeled liposomes (PS/PC, 3:1 molar ratio) for $1 \mathrm{~h}$ at $37^{\circ} \mathrm{C}$ and collected by centrifugation at $39,000 \mathrm{~g}$ for $30 \mathrm{~min}$ at $4^{\circ} \mathrm{C}$. IOVs were then washed twice and the amount of bound liposomes was determined by the residual liposome radioactivity contained in the washed membrane pellet. IOVs were quantitated as micrograms membrane phosphorus. IOV protein 4.1 content was determined by quantitative densitometry of Coomassie Bluestained SDS-PAGE gels. Protein 4.1-depleted IOVs were prepared from normal IOVs by incubation with $1 \mathrm{M}$ potassium iodide, which extracts ankyrin, protein 4.1, and protein 4.2. Protein 4.1-repleted IOVs were prepared by incubating protein 4 .1-depleted IOVs with purified 4.1. Results are the mean \pm 1 SD of 4 individual determinations.

* Statistically different from normal at $P<0.01$.

\section{Discussion}

It is now firmly established that the four major classes of phospholipids that comprise the human RBC plasma membrane (PC, PE, PS, and SM) are distributed asymmetrically between the bilayer leaflets (1). This asymmetric distribution results in the exoplasmic leaflet being enriched in the choline-containing phospholipids PC and SM, whereas the cytoplasmic leaflet contains the majority of PE and all of the PS. Several lines of evidence indicate that this asymmetry is maintained through specific interactions between individual phospholipids and membrane cytoskeletal proteins. First, RBCs whose membrane proteins are damaged by protein oxidants $(8,40)$ demonstrate a loss of membrane phospholipid asymmetry. Secondly, incubations of RBCs with exogenous sources of PS re-

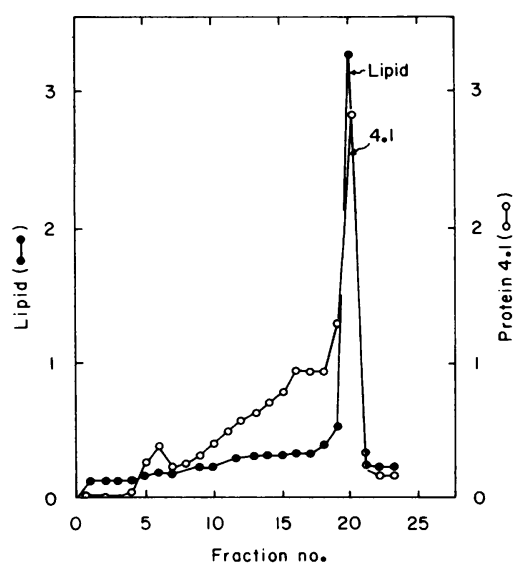

Figure 3. A representative $10-30 \%$ Ficoll 400 discontinuous density gradient for the separation of liposome-bound protein from free protein. $3 \mathrm{ml}$ of the $10 \%$ Ficoll-liposome-protein incubation mixture and $0.5 \mathrm{ml}$ of $5 \mathrm{mM}$ sodium Hepes, $\mathrm{pH} 7.4$, containing $140 \mathrm{mM}$ $\mathrm{NaCl}$ were layered over $1 \mathrm{ml} \mathrm{30 \%} \mathrm{Ficoll} \mathrm{and}$ centrifuged for $1 \mathrm{~h}$ at $25^{\circ} \mathrm{C}$ in a rotor $(\mathrm{SW}$ 50.1 , Beckman Instruments, Inc.) at 35,000 rpm. Fractions were collected from the bottom of the centrifuge tube and ( $\bullet$ ) liposome content determined by phosphorus determination and ( 0 ) protein 4.1 content determined by ${ }^{125}$ I-radioactivity.

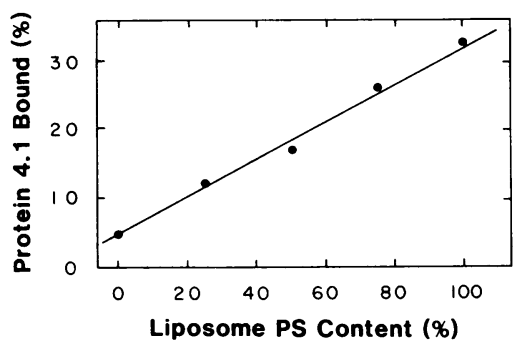

Figure 4. Protein 4.1 binding to liposomes. Radiolabeled protein $4.1(5 \mu \mathrm{g})$ was incubated with $50 \mathrm{nmol} \mathrm{li}$ posomes in a total volume of $0.25 \mathrm{ml}$ for 30 $\min$ at $37^{\circ} \mathrm{C}$. Liposome bound ${ }^{125} \mathrm{I}$-protein 4.1 was separated from unbound protein by centrifugation through a discontinuous $10-30 \% \mathrm{Fi}-$ coll $\mathbf{4 0 0}$ gradient, as described in Fig. 3. Data points represent the average of duplicate determinations and were corrected for $2 \%$ nonspecific protein binding to liposomes evaluated using a heat-denatured $\left(65^{\circ} \mathrm{C}\right.$ for $\left.20 \mathrm{~min}\right)$ protein $4.1 \mathrm{control}$. The line drawn was a best fit determined by linear regression analysis.

sults in the uptake of PS into the exoplasmic bilayer leaflet followed by translocation into the cytoplasmic leaflet; the rate and extent of the translocation being dependent on the PS acyl-chain composition and the metabolic state of the cell $(4$, $41)$. Once translocated into the cytoplasmic leaflet this exogenously added PS is maintained in that leaflet, as evidenced by the inability to quench spin-labeled PS with exogenously added reducing agents (4), and by the irreversible nature of stomatocytic shape changes induced by its incorporation into the cytoplasmic leaflet (41). Thirdly, RBC membrane phospholipid asymmetry is maintained throughout the 120 -d average lifespan of the cells (5), despite the fact that dynamic bilayer translocation of phospholipids does occur in intact cells $(3,4)$.

The work presented in this paper was undertaken to examine the interactions between protein 4.1 and PS. A previous report by Sato and Ohnishi (15) demonstrated that RBC protein 4.1 interacts with PS liposomes and protease-digested IOV membranes. We hypothesized that such interactions could stabilize PS in the cytoplasmic leaflet of RBC plasma membranes. To test this hypothesis, we used RBCs that completely lacked protein 4.1 but contained normal amounts of all other membrane peripheral proteins (HE[4.1 $\left.\left.{ }^{\circ}\right]\right)$. The morphology of these cells was abnormal in that most cells were elliptocytic. Despite the presence of a normal amount of spectrin in these cells, we found that $\sim 10 \%$ of the total membrane content of PS was accessible for hydrolysis by PLA $\mathrm{A}_{2}$ and SMC, whereas in normal RBCs no PS was hydrolysed by this treatment. The bilayer distribution of PE and SM was not affected in these

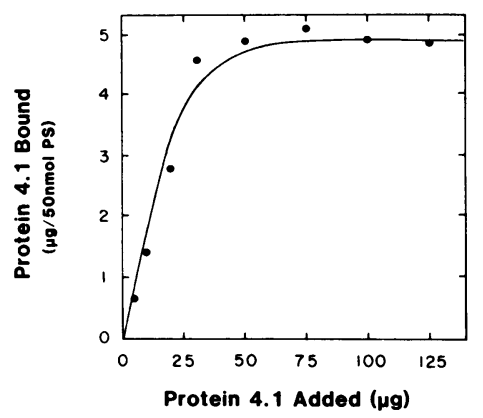

Figure 5. Binding isotherm of radiolabeled normal protein 4.1 to PS liposomes. Increasing amounts of ${ }^{125} \mathrm{I}$ protein $4.1(5-125 \mu \mathrm{g})$ were incubated with $50 \mathrm{nmol} \mathrm{li-}$ posomes in a total volume of $0.25 \mathrm{ml}$ for $30 \mathrm{~min}$ at $37^{\circ} \mathrm{C}$. Liposome-bound ${ }^{125}$ I-protein 4.1 was separated from free protein by centrifugation through a discontinous Ficoll 400

density gradient and liposome and protein contents quantitated, as described in Fig. 3. Data points represent the average of duplicate determinations. 
cells although there was some redistribution of PC from the exoplasmic to the cytoplasmic leaflet, presumably to maintain an equimolar amount of total phospholipid in each bilayer leaflet. Note that differences in cell hemolysis caused by treatment with the phospholipases can affect the amount of phospholipids hydrolysed. However, our experience, and those of others using phospholipases to examine membrane phospholipid asymmetry, shows that below $10 \%$ hemolysis there is a $0.1 \%$ increase in PS degradation for every $1 \%$ increase in hemolysis. This increase is attributable to penetration of the enzymes into the cell interior. Therefore, at $6 \%$ hemolysis (measured for the $\left.\mathrm{HE}\left[4.1^{\circ}\right] \mathrm{RBCs}\right)$ we would expect only $0.6 \%$ artefactual PS degradation, which could not account for the $10 \%$ degradation of PS measured in the HE[4.1 $\left.{ }^{\circ}\right]$ cells. Also, note that in the HE[4.1 $1^{\circ}$ RBCs only the transmembrane distribution of PS was found to be altered; in other pathologic RBCs that we have examined, in which the primary membrane defect is thought to involve spectrin, such as in sickle cells and spectrin-deficient cells, bilayer redistributions of both PE and PS were always observed together (5).

Membranes from $\mathrm{HE}\left[4.1^{\circ}\right] \mathrm{RBCs}$ are also $>80 \%$ deficient in glycophorin C (synonyms PAS-2, glycoconnectin), a minor sialoglycoprotein in the RBC membrane (14). To determine whether the absence of glycophorin $C$ contributed to the availability of PS in the exoplasmic leaflet of the HE[4.1 ${ }^{\circ}$ RBCs, we examined membrane phospholipid organization in RBCs lacking the Gerbich blood group $\left(\mathrm{Ge}^{-}\right)$antigen. $\mathrm{Ge}^{-} \mathrm{RBCs}$ differ from normal RBCs in that they completely lack glycophorin $\mathrm{C}$, but contain normal amounts of all other cytoskeletal proteins, including protein 4.1 (reference 36 and confirmed in our laboratory). We found that $\mathrm{Ge}^{-} \mathrm{RBCs}$ did not have any PS in the membrane exoplasmic leaflet, confirming previous observations of Kuypers et al. (39). These observations strongly suggest that it was the absence of protein 4.1, and not a deficiency of glycophorin $\mathrm{C}$, which was principally responsible for the abnormal increased availability of PS in the exoplasmic leaflet of the HE[4.1 $\left.{ }^{\circ}\right]$ RBCs.

We next evaluated PS liposome binding capacity to IOVs derived from normal, protein 4.1-depleted, and $\mathrm{HE}\left[4.1^{\circ}\right]$ RBC membranes. Normal IOVs are spectrin-actin-depleted but contain protein 4.1, the presence of which enhanced PS liposome binding as compared with either the protein 4.1-depleted or the $\mathrm{HE}\left[4.1^{\circ}\right]$ IOVs. The differences were, however, relatively small $(\sim 20 \%)$ presumably because much of the protein 4.1 in IOVs is already bound to PS. Interestingly, IOVs from both protein 4.1-depleted and $\mathrm{HE}\left[4.1^{\circ}\right]$ membranes, which contained different amounts of ankyrin and protein 4.2, had very similar PS liposome binding capacities, suggesting that neither ankyrin nor protein 4.2 significantly influences the capacity of IOVs to bind PS liposomes. Restoration of PS liposome binding to protein 4.1 repleted IOVs demonstrated the specificity of protein 4.1 in PS liposome binding.

When the interaction of protein 4.1 with different classes of phospholipids was characterized, we found that the extent of protein 4.1 binding was directly proportional to liposome PS content. The binding of protein 4.1 to PS liposomes was saturable, at saturation $\sim 100 \mu \mathrm{g}$ protein 4.1 bound $/ \mu \mathrm{mol}$ PS.

Protein 4.1 is known to interact with other membrane proteins, including spectrin-actin (30), glycophorin (13), and band 3 (42). Furthermore, PS model membranes bind to spectrin in vitro $(6,7)$. Therefore, it is likely that both protein 4.1 and PS have multiple membrane attachment sites. Within this context, the interactions between protein 4.1 and PS liposomes should not be taken as representing a true physiologic situation in that competition of protein 4.1 or PS for other membrane binding sites, as would almost certainly occur in intact RBC membranes, is not considered in these simplified isolated systems. Nevertheless, our data indicates that protein 4.1 is a PS binding protein since $(i)$ its absence from $\mathrm{HE}\left[4.1^{\circ}\right] \mathrm{mem}-$ branes is associated with a bilayer redistribution of PS; $(i i)$ the reassociation of protein 4.1 with protein 4.1-stripped membranes results in enhanced PS binding, and (iii) protein 4.1 binds saturably to PS liposomes where the extent of protein 4.1 binding is proportional to the membrane PS content.

\section{Acknowledgments}

The authors thank Drs. Thomas Mueller and Winfred Wang for providing the HE[4.1 $\left.{ }^{\circ}\right]$ RBCs, Drs. David Anstee and Narla Mohandas for providing the Gerbich negative blood, and Drs. Danny Chiu and Maggie Yee for performing the RBC membrane phospholipid sidedness assays. We thank Dr. Thomas Mueller for providing us with a photograph of SDS-PAGE-separated HE $\left[4.1^{\circ}\right]$ RBC membranes and Dr. Yi-Quin Lu for performing the membrane glycophorin characterizations. We also sincerely appreciate the expert secretarial assistance of Mrs. M. Douglass.

This work was supported by National Institutes of Health grants HL-33084, HL-27059, and AM-32094, and Biomedical Research Support grant RR-05467.

\section{References}

1. Op den Kamp, J. A. F. 1979. Lipid asymmetry in membranes. Ann. Rev. Biochem. 48:47-71.

2. van Meer, G., and J. A. F. Op den Kamp. 1982. Transbilayer movement of various phosphatidylcholine species in intact human erythrocytes. J. Cell Biochem. 19:193-204.

3. Franck, P. F. H., D. T. Y. Chiu, J. A. F. Op den Kamp, B. Lubin, L. L. M. van Deenen, and B. Roelofsen. 1983. Accelerated transbilayer movement of phosphatidylcholine in sickled erythrocytes. J. Biol. Chem. 258:8435-8442.

4. Seigneuret, M., and P. F. Devaux. 1984. ATP-dependent asymmetric distribution of spin-labeled phospholipids in the erythrocyte membrane: relation to shape changes. Proc. Natl. Acad. Sci. USA. 81:3751-3755.

5. Schwartz, R. S., D. T. Y. Chiu, and B. Lubin. 1985. Plasma membrane phospholipid organization in human erythrocytes. Curr. Top. Hematol. 5:63-112.

6. Mombers, C., J. de Gier, R. A. Demel, and L. L. M. van Deenen. 1980. Spectrin-phospholipid interaction: A monolayer study. Biochim. Biophys. Acta. 603:52-62.

7. Mombers, C., A. J. Verkleij, J. de Gier, and L. L. M. van Deenen. 1979. The interaction of spectrin-actin and synthetic phospholipids. II. The interaction with phosphatidylserine. Biochim. Biophys. Acta. 551:271-281.

8. Haest, C. W. M., G. Plasa, D. Kamp, and B. Deuticke. 1978. Spectrin as a stabilizer of the phospholipid asymmetry in human erythrocyte membranes. Biochim. Biophys. Acta. 509:21-32.

9. Haest, C. W. M. 1982. Interactions between membrane skeletal proteins and the intrinsic domain of the erythrocyte membrane. Biochim. Biophys. Acta. 694:331-352.

10. Scott, S., S. A. Pendlebury, and C. Green. 1984. Lipid organization in erythrocyte membrane microvesicles. Biochem. J. 224:285290.

11. Williamson, P., J. Bateman, K. Kozarsky, K. Mattocks, N. Hermanowicz, H.-R. Choe, and R. A. Schlegel. 1982. Involvement of spectrin of the maintenance of phase-state asymmetry in the erythrocyte membrane. Cell. 30:725-733. 
12. Cohen, C. 1983. The molecular organization of the red cell membrane skeleton. Semin. Hematol. 20:141-158.

13. Anderson, R. A., and R. E. Lovrien. 1984. Glycophorin is linked by band 4.1 protein to the human erythrocyte membrane skeleton. Nature (Lond.). 307:655-658.

14. Mueller, T. J., and M. Morrison. 1981. Glycoconnectin (PAS 2), a membrane attachment site for the human erythrocyte cytoskeleton. In Erythrocyte Membranes 2: Recent Clinical and Experimental Advances. W. C. Kruckeberg, J. W. Eaton, and G. J. Brewer, editors. Alan R. Liss, Inc., New York. 95-112.

15. Sato, S. B., and S. Ohnishi. 1983. Interaction of a peripheral protein of the erythrocyte membrane, band 4.1, with phosphatidyiserine containing liposomes and erythrocyte inside out vesicles. Eur. $J$. Biochem. 130:19-25.

16. Dodge, J. T., C. Mitchell, and D. J. Hanahan. 1963. The preparation and chemical characteristics of hemoglobin-free ghosts of the human erythrocyte. Arch. Biochem. Biophys. 100:119-130.

17. Steck, T. L., and J. A. Kant. 1974. Preparation of impermeable ghosts and inside out vesicles from human erythrocyte membranes. Methods Enzymol. 31:172-179.

18. Beutler, E. 1984. Red Cell Metabolism: A Manual of Biochemical Methods. Grune \& Stratton Inc., Orlando, Florida. 188 pp.

19. Bennett, V., and P. J. Stenbuck. 1980. Association between ankyrin and the cytoplasmic domain of band 3 isolated from the human erythrocyte membrane. J. Biol. Chem. 255:6424-6432.

20. Shiffer, K. A., and S. R. Goodman. 1984. Protein 4.1: its association with the human erythrocyte membrane. Proc. Natl. Acad. Sci. USA. 81:4404-4408.

21. Lubin, B., D. Chiu, J. Bastacky, B. Roelofsen, and L. L. M. van Deenen. 1981. Abnormalities in membrane phospholipid organization in sickled erythrocytes. J. Clin. Invest. 67:1643-1649.

22. Rose, H. G., and M. Oklander. 1965. Improved procedures for the extraction of lipids from human erythrocytes. J. Lipid Res. 6:428431.

23. Roelofsen, B., and R. F. A. Zwaal. 1976. The use of phospholipases in the determination of asymmetric phospholipid distribution in membranes. Methods Membr. Biol. 7:147-177.

24. Bartlett, G. R. 1959. Phosphorus assay in column chromatography. J. Biol. Chem. 234:466-468.

25. Szoka, F., and D. Papahadjopoulos. 1978. Procedure for preparation of liposomes with large internal aqueous space and high capture by reverse phase evaporation. Proc. Natl. Acad. Sci. USA. 75:41944198.

26. Wilschut, J., N. Düzgünes, R. Fraley, and D. Papahadjopoulos. 1980. Studies on the mechanism of membrane fusion: kinetics of calcium induced fusion of phosphatidylserine vesicles followed by a new assay for mixing of aqueous vesicle contents. Biochemistry. 19:60116021.

27. Olson, F., C. A. Hunt, F. C. Szoka, W. J. Vail, and D. Papahadjopoulos. 1979. Preparation of liposomes of defined size distribution by extrusion through polycarbonate membranes. Biochim. Biophys. Acta. 557:9-23.
28. Szoka, F., F. Olson, T. Heath, W. Vail, E. Mayhew, and D. Papahadjopoulos. 1980. Preparation of unilamellar liposomes of intermediate size $(0.1-0.2 \mu \mathrm{m})$ by a combination of reverse phase evaporation and extrusion through polycarbonate membranes. Biochim. Biophys. Acta. 601:559-571.

29. Tyler, J. M., B. N. Reinhardt, and D. Branton. 1980. Associations of erythrocyte membrane proteins: binding of purified bands 2.1 and 4.1 to spectrin. J. Biol. Chem. 255:7034-7039.

30. Cohen, C. M., and S. F. Foley. 1984. Biochemical characterization of complex formation by human erythrocyte spectrin, protein 4.1 and actin. Biochemistry. 23:6091-6098.

31. Bradford, M. M. 1976. A rapid and sensitive method for the quantitation of microgram quantities of protein utilizing the principle of protein dye binding. Anal. Biochem. 72:255-260.

32. Laemmli, U. K. 1970. Cleavage of structural proteins during the assembly of the head of bacteriophage T4. Nature (Lond.). 227:680-685.

33. Bolton, A. E., and W. M. Hunter. 1973. The labelling of proteins to high specific radioactivities by conjugation to a ${ }^{125}$ I containing acylating agent. Biochem. J. 133:529-539.

34. Steck, T. L. 1974. The organization of proteins in the human red blood cell membrane. J. Cell Biol. 62:1-19.

35. Towbin, H., T. Staehelin, and J. Gordon. 1979. Electrophoretic transfer of proteins from polyacrylamide gels to nitrocellulose sheets: procedure and some applications. Proc. Natl. Acad. Sci. USA. 76:4350-4354.

36. Anstee, J. D., S. F. Parsons, K. Ridgwell, M. J. A. Tanner, A. H. Merry, E. E. Thomson, P. A. Judson, P. Johnson, S. Bates, and I. D. Fraser. 1984. Two individuals with elliptocytic red cells apparently lack three minor erythrocyte membrane sialoglycoproteins. Biochem. J. 218:615-619.

37. Lu, Y.-Q., M. E. Nichols, W. L. Bigbee, R. L. Nagel, and O. O. Blumenfeld. 1987. Structural polymorphism of glycophorins demonstrated by immunoblotting techniques. Blood. 69:618-624.

38. Glossmann, H., and D. M. Neville. 1971. Glycoproteins of cell surfaces: a comparative study of three different cell surfaces of the rat. J. Biol. Chem. 246:6339-6346.

39. Kuypers, F. A., M. v. L.-S. Trip, B. Roelofsen, J. A. F. Op den Kamp, M. J. A. Tanner, and D. J. Anstee. 1985. The phospholipid organisation in the membranes of McLeod and Leach phenotype erythrocytes. FEBS (Fed. Eur. Biochem. Soc.) Lett. 184:20-24.

40. Haest, C. W. M., and B. Deuticke. 1976. Possible relationship between membrane proteins and phospholipid asymmetry in the human erythrocyte membrane. Biochim. Biophys. Acta. 436:353-365.

41. Daleke, D. L., and W. H. Huestis. 1985. Incorporation and translocation of aminophospholipids in human erythrocytes. Biochemistry. 24:5406-5416.

42. Pasternack, G. R., R. A. Anderson, T. L. Leto, and V. T. Marchesi. 1985. Interactions between protein 4.1 and band 3. J. Biol. Chem. 260:3676-3683. 